\title{
Salmonellosis in Poultry: A Case Report
}

\author{
T. Vijaya Nirmala ${ }^{1 *}$, A. Devivaraprasad Reddy ${ }^{1}$, E. Karuna Sree ${ }^{1}$, \\ K. Venkata Subbaiah ${ }^{1}$, G. Shali Raju ${ }^{1}$ and R.V.S.K. Reddy ${ }^{2}$ \\ ${ }^{1}$ Krishi Vigyan Kendra, Dr YSR Horticultural University, Venkataramannagudem, \\ West Godavari district, Andhra Pradesh - 534 101, India \\ ${ }^{2}$ Dr YSR Horticultural University, Venkataramannagudem, West Godavari district, \\ Andhra Pradesh - 534 101, India \\ *Corresponding author
}

\section{A B S T R A C T}

\section{Keywords}

Salmonella,

Salmonellosis,

Poultry, Case

report, Treatment

Article Info

Accepted:

20 January 2018

Available Online:

10 February 2018
Salmonellosis poses a high risk in the poultry birds and widely distributed worldwide. It results in huge economic loss and very difficult in control of disease. The clinical signs are reduced feed intake, droopiness, ruffled feathers, huddling of chicks and diarrhoea, dehydration, and mortality were reported. The morbid chicks were investigated for post mortem changes and gross lesions include livers were invariably enlarged, soft in consistency, congested and showed bronze discoloration. The birds were treated with furazolidone antibiotic and found to be effective against the Salmonella infection of poultry. General hygienic and biosecurity measures should be part of the overall management plan of poultry farms for effective control of bacterial infection.

\section{Introduction}

Salmonella belongs to Enterobacteriaceae family with more than 2300 serovars and causing Salmonellosis. Salmonella are gramnegative, facultative anaerobic, rod shaped, non-spore forming bacteria. They are usually motile, catalase-positive, oxidase and ureasenegative. They reduce nitrates and use citrate as the sole carbon source and do not deaminate phenylalanine and ferment lactose (Jeyasekaran et al., 2011). Fowl typhoid (FT) and pullorum disease (PD) are septicaemic diseases and are caused by S. gallinarum and
S. Pullorum respectively which are host specific Salmonella in poultry birds. These stains does not possess zoonotic potential like $S$. typhimurium or $S$. enteritidis, but they cause severe mortality among poultry birds which results in massive economic loss (Shivaprasad, 2000; Rajagopal and Mini, 2013). Once this Salmonella infection has established in a primary breeding flock, it can infect the other units very easily through hatcheries via vertical and horizontal ways. These poultry birds act a reservoir for transmission of disease to the other noninfected birds. Hence, it is far ranging and 
serious effects on the health of both poultry and humans. Therefore there is a dire need to prevent the infection from the breeding flock.

\section{Case history and observations}

A case was reported in the poultry farm located at Venkataramannagudem Village, West Godavari District during the month of August, 2017. A few morbid chicks of 812days of age were presented for investigation. It was reported that the day old chicks were weak and died after showing the clinical signs. Clinical signs were reported that the reduced feed intake, droopiness, ruffled feathers, huddling of chicks and diarrhoea, dehydration, mortality. At necropsy, the livers were invariably enlarged, soft in consistency, congested and showed bronze discoloration and it was found that infected with Salmonella spp. The gross lesions were similar to the findings of the Shivaprasad (2000).

\section{Results and Discussion}

Salmonella belong to either of the two species i.e. S.enterica and S. bongori and based on the host adaptation it is classified into three groups i.e. typhoid, non-typhoid and specific host interactions (Karunasagar et al., 2012). Salmonella causing infections especially specific host such as $S$. gallinarum and $S$. pullorum in poultry birds. Since this Salmonellosis cause huge economic impact especially in poultry and is distributed worldwide (Rajagopal and Mini, 2013). Consumption of contaminated food and water results in the Salmonella infection. Salmonella remain as a serious economic problem to livestock in countries where measures of control are not efficient or in those where the climatic conditions favour the environmental spread of these microorganisms (Barrow et al., 2011). Rajagopal and Mini (2013) found that the maximum Salmonella outbreak in the age group of 7-9 days and the maximum mortality was found in the age group of 1-2 weeks old.

Based on the clinical signs, the treatment has been started with furazolidone at the rate of $400 \mathrm{grams} / 1$ ton of feed and found to be very effective against Salmonellosis. Since this furazolidone is a nitrofuran derivative with bacteriostatic and bactericidal activity against Gram positive bacteria and Gram negative bacteria. Various other antibiotics can be used for controlling and treating Salmonellosis, including sulphonomides, chloramphenicol, biomycin, oxytetracycline, apramycin, gentamicin, amoxycillin, potentiated sulponamide, tetracylines, fluoroquinolones and chlorotetracycline (Aziz et al., 1997; McMullin 2004; Taddele et al., 2012; Rajagopal and Mini, 2013). In addition, disinfection of the entire farm by formaldehyde spraying and fumigation also helped in control of the disease. Disinfection and eradication measures are extremely tedious and chances of further infections are many fold after an initial attack.

The control of Salmonella is difficult since it can remain in the environment and transform into biofilm. Rodents also play an important role in the persistence of Salmonella in poultry farms (Meerburg and Kijlstra, 2007). All manure was scraped from floors and walls and all feeding and watering equipments were disinfected. A disinfectant containing a phenolic active ingredient, with a label claiming bactericidal effects on Salmonella spp., was sprayed on all surfaces of items listed above. Feeding and watering equipment were placed outdoors in the sunlight. The success of this cleanup effort was due in part to a determined owner and was aided by relatively high environmental temperatures during the cleaning and disinfection process, which reduced the probability of survival of $S$. pullorum that may have remained in the 
environment after depopulation of the affected flock.

Salmonella can be controlled by strictly following biosecurity measures such as disinfection or cleaning of hatching eggs, salmonella free brood stock, good hygiene conditions in the farm will eradicate the salmonellosis. Timely treatment is required to control the bacterial infections. Prevention is better than cure.

\section{References}

Aziz N.S.A., Satija K.C. and Garg D.N. (1997). The efficacy of gentamicin for the control of egg-borne transmission of Salmonella gallinarum. Indian Vet. J., 74: 731-733.

Jeyasekaran, G., Thirumalai Raj, K., Jeya Shakila, R. Jemila Thangarani, A., Sukumar, D. and Abdul Kadhar Jailani, V., (2011) Rapid detection of Salmonella enterica serovars by multiplex PCR. World J Microbiol. Biotechnol, 27: 953-959.

Karunasagar, I, Bhowmick, P.P. and Deekshit
V.K. (2012) Molecular Aspects of Pathogenesis and Drug Resistance in Salmonella Species. In: Foodborne and Waterborne Bacterial Pathogens Epidemiology, Evolution and Molecular Biology. Edited by Shah M. Faruque. Caister Academic Press Norfolk, UK. Pp. 121-152.

McMullin, P. (2004). A pocket guide to poultry health and disease. 278pg.

Meerburg, B.G. and Kijlstra, A. (2007) Role of rodents in transmission of Salmonella and Campylobacter. J Sci Food Agric. 81: 2774-2781.

Rajagopal, R. and Mini, M. (2013) Outbreaks of salmonellosis in three different poultry farms of Kerala, India. Asian Pac J Trop Biomed 3(6): 496-500

Shivaprasad, H.L. (2000) Fowl typhoid and pullorum disease. Rev Sci Tech. 19(2): 405-424.

Taddele, M.H., Rathore, R. and Dhama, K. (2012) Antibiogram assay of $S$. gallinarum and other $S$. enteric serovars of poultry origin in India. Asian J Anim Vet Adv. 7: 309-317.

\section{How to cite this article:}

Vijaya Nirmala, T., A. Devivaraprasad Reddy, E. Karuna Sree, K. Venkata Subbaiah, G. Shali Raju and Reddy, R.V.S.K. 2018. Salmonellosis in Poultry: A Case Report. Int.J.Curr.Microbiol.App.Sci. 7(02): 2347-2349. doi: https://doi.org/10.20546/ijcmas.2018.702.285 